\title{
PEMERIKSAAN PROSTATE-SPECIFIC ANTIGEN (PSA) METODE IMUNOKROMATOGRAFI PADA BERCAK CAIRAN MANI DALAM PEMBUKTIAN PERSETUBUHAN
}

\author{
Juli Purwo Jatmiko*1, Ahmad Yudianto ${ }^{2}$, Puspa Wardhani ${ }^{3}$ \\ Prodi S2 Ilmu Forensik, Sekolah Pascasarjana Universitas Airlangga \\ Instalasi Kedokteran Forensik, Rumah Sakit Dr. Soetomo Surabaya \\ Departemen Patologi Klinik Fak. Kedokteran Universitas Airlangga \\ Email : alexpurwojatmiko@yahoo.com.
}

\begin{abstract}
Sexual crime is increasing in Indonesia, both occur in big cities and rural areas who still hold traditional values, especially in societies whose economy is weak. Forensic Medicine plays a very vital in handling cases of sexual crime. One role of forensic medicine in helping to uncover cases of sexual crimes, especially rape is to prove the existence of signs of sexual intercourse, namely the discovery of the semen or sperm cells. Quite a long time interval between the time of the incident with the examination makes the process of finding sperm cells and seminal fluid becomes increasingly difficult. Examination of vaginal smears to prove the existence of ejaculate will give unsatisfactory results, since it is still possible when examination materials can be obtained from the underwear worn at the time of the incident. Current inspection methods are simple semen still have a false positive values are quite high, while the use of sophisticated methods are difficult to apply in routine services. Has recently been developed rapid test SD Bioline Cement Inspection which has a value of sensitivity and specificity that is high enough to find their prostate-specific antigen (PSA) which is one of the content in seminal fluid. With this method is expected to be an alternative in case of proof of sexual crimes.
\end{abstract}

Key words: Sexual crime, prostate-spesific antigen (PSA), rapid test.

\section{PENDAHULUAN}

Tindak pidana pemerkosaan merupakan suatu persoalan yang serius dalam kehidupan bermasyarakat, karena selain menjadi beban secara fisik maupun psikis pada korban. Berkembangnya situs jejaring sosial yang diiringi dengan kemajuan teknologi komunikasi akhir-akhir ini turut memicu terjadinya kejahatan seksual yang awalnya bermula dari email, messaging, chatting hingga ke cyber sex. Oleh karena itu, wajar saja bila para praktisi di bidang kesehatan sering menjumpai korban-korban kejahatan seksual dengan berbagai masalah kesehatan yang akut dan kronis yang diderita oleh korban (Melia, 2012
Bukti forensik bukan merupakan satusatunya dasar pertimbangan bagi hakim untuk membuktikan kasus perkosaan, namun sering digunakan untuk mendukung dan menguatkan alat bukti yang lain seperti pengakuan korban dan keterangan saksi. Oleh karena itu, bukti forensik harus didapatkan sebanyak-banyaknya (Idries, 2011). Salah satu peran kedokteran forensik dalam membantu mengungkap kasus kejahatan seksual terutama pemerkosaan adalah dengan membuktikan adanya tanda-tanda persetubuhan. Secara medis, persetubuhan didefinisikan sebagai peristiwa terjadinya penetrasi penis ke dalam vagina, yang mana penetrasi tersebut dapat lengkap atau tidak 
lengkap dengan atau tanpa disertai ejakulasi (Idries, 2011).

Dalam pembuktian kasus-kasus persetubuhan sangatlah tidak mudah oleh karena sebagian besar kasus-kasus kejahatan tidak ada saksi, minimnya barang bukti petunjuk dan berbagai kesulitan lainnya. Anamnesis dan pemeriksaan fisik yang dilakukan oleh dokter pemeriksa memiliki nilai keragu-raguan yang cukup besar. Anamnesis Kedokteran forensik yang didapat dari korban tidak sama tingkat kebenarannya dibandingkan anamnesis kedokteran klinik yang lain (Idries, 2011).

Pemeriksaan laboratorium sederhana untuk menentukan adanya cairan mani pada vagina dengan menggunakan metode Kristal kholin, spermin, fosfatase asam dan seng sangat bermanfaat untuk mendukung pembuktian. Namun belum cukup untuk memastikan adanya persetubuhan. Selain memiliki nilai pembuktian yang kecil, pada kenyataan dilapangan terdapat pula permasalahan yang lain, yaitu bahan sampel yang akan dilakukan pemeriksaan sudah cukup lama. Komponen yang dianggap paling spesifik untuk cairan mani yang dapat diterima secara umum adalah Prostat-Spesific Antigen (PSA). Dengan demikian, ditemukannya PSA didalam cairan vagina memastikan telah terjadi persetubuhan (Manfred, et al., 1999 ; Hardinge, et al., 2013). Pemeriksaan PSA dalam vagina pada kasus kejahatan seksual secara kuantitatif sulit dilakukan karena biaya yang cukup mahal, sehingga jarang dilakukan sebagai penunjang pemeriksaan. Namun, seiring dengan perkembangan teknologi, saat ini telah ditemukan tes cepat dengan metode imunokromatografi untuk pemeriksaan PSA (rapid test SD BIO LINE SEMEN INSPECTION) yang lebih praktis, hemat waktu, mudah dilakukan, relatif murah, serta mempunyai nilai sensitif dan spesifik yang cukup baik, sehingga dapat dipergunakan sebagai tes penentuan untuk memastikan persetubuhan (Leonardo, 2015).

Apabila waktu pemeriksaan dengan saat kejadian memiliki interval waktu yang cukup lama, terlebih korban sudah membersihkan diri serta mandi, akan sangat sulit ditemukan adanya cairan mani ataupun sperma dalam vagina korban. Oleh karena itu, pemeriksaan untuk membuktikan adanya persetubuhan atau perkosaan, bahan pemeriksaan dapat diambil dari bercak yang terdapat pada pakaian dalam korban yang dikenakan pada saat kejadian, itupun dengan syarat pakaian tersebut belum dicuci oleh korban. Hal tersebut dapat dilakukan mengingat cairan mani yang berada dalam vagina akan menetes atau keluar dan menempel pada pakaian dalam saat korban berdiri ataupun berjalan. Bercak cairan mani pada kain mempunyai sifat yang lebih stabil dibandingkan cairan mani pada vagina (Idries, 2011). Sifat stabil tersebut disebabkan oleh karena protein yang terdapat dalam cairan mani tidak dapat lagi diurai atau dilisis oleh bakteri dikarenakan sudah dalam keadaan kering. Cairan mani yang terdapat pada kain mempunyai karakteristik yang berbeda-beda tergantung jenis bahan kain, akan tetapi secara umum bercak cairan mani mempunyai sifat keras pada perabaan (seperti kanji) dan berwarna kekuningan serta berflourence pada pemeriksaan dengan sinar ultra violet (UV) (Idries, 2011)

Atas dasar itulah peneliti akan melakukan pengujian terhadap celana dalam yang mengandung bercak cairan mani untuk dilakukan pemeriksaan PSA dan sampai berapa lama masih memberikan hasil positif, sehingga pemeriksaan ini dapat digunakan untuk kepentingan forensik.

\section{RUMUSAN MASALAH}

Berapa lama waktu yang masih memberikan hasil positif pada pemeriksaan PSA SD BIOLINE SEMEN INSPECTION dari bahan pemeriksaan yang berasal dari bercak cairan mani pada celana dalam.

\section{MATERI DAN METODE PENELITIAN}

\subsection{Desain Penelitian}

Penelitian ini merupakan penelitian deskriptif dengan melakukan pemeriksaan terhadap bercak cairan mani pada celana dalam dengan 
menggunakan rapid test SD BIOLINE SEMEN INSPECTION secara kualitatif. Sampel diperoleh dari cairan mani yang berasal dari laki-laki yang memenuhi kriteria penerimaan dan penolakan. Perhitungan besar sampel pada penelitian ini tidak dapat dilakukan karena tidak ada data sebelumnya sehingga peneliti dalam menentukan besar sampel menggunakan teori Thomas Bayes, dimana peneliti menetapkan jumlah minimal sebesar 30 sampel. Sebagai cadangan bila salah satu volume sampel kurang, maka peneliti menambahkan 5 sampel sebagai cadangan sehingga didapatkan besar sampel 35 .

\subsection{Tempat Dan Waktu Penelitian}

Penelitian ini dilaksanakan di ruang Laboratorium Instalasi Kedokteran Forensik Rumah Sakit Bhayangkara Tingkat I R. Said Sukanto, Jakarta Timur antara bulan Juni hinga Agustus 2015

\section{HASIL PENELITIAN, HASIL PEMERIKSAAN DAN HASIL PEMBAHASAN}

\subsection{Hasil Penelitian}

Seluruh subjek yang mengikuti penelitian ini adalah laki-laki yang belum menikah, dengan usia termuda 20 tahun dan usia tertua 26 tahun, rerata usia subjek adalah 23 tahun. Volume cairan mani yang didapatkan tiap ejakulasi dari relawan berkisar antara 3,0 $\mathrm{ml}$ sampai 4,5

Sebelum dilakukan pemeriksaan dengan rapid tes SD Bioline Semen Inspection, peneliti melakukan persiapan terhadap cairan mani yang diperoleh dari sukarelawan yaitu, mengukur volume cairan mani, kemudian cairan mani tersebut dibercakan pada celana dalam. Selanjutnya celana dalam yang sudah mengandung bercak cairan mani didiamkan dalam suhu kamar hingga kering. Keesokan harinya bercak tersebut dilakukan pemeriksaan hari pertama menggunakan rapid tes.

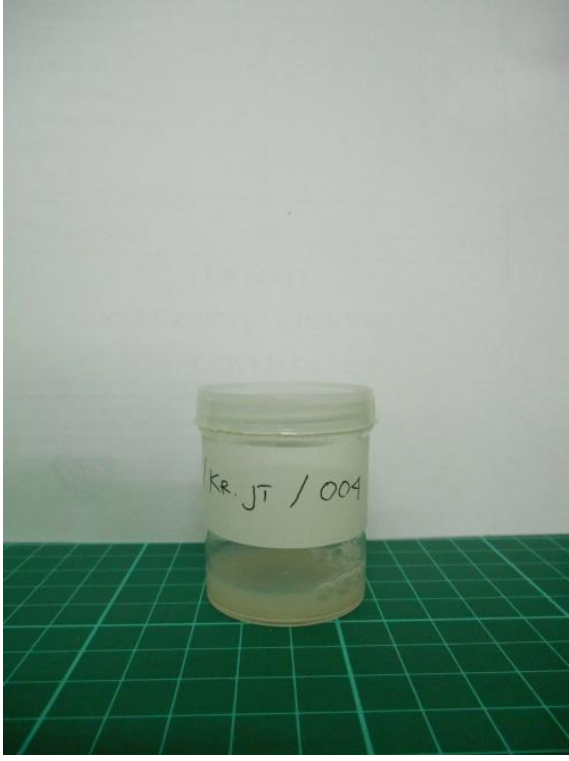

Gambar 1. Cairan mani subjek penelitian

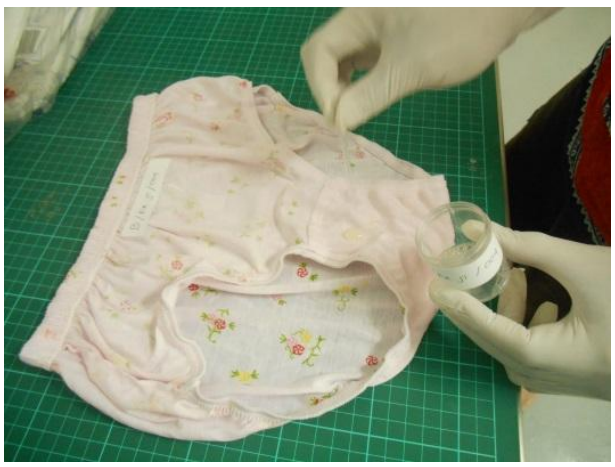

Gambar 2. Cairan mani dibuat bercak

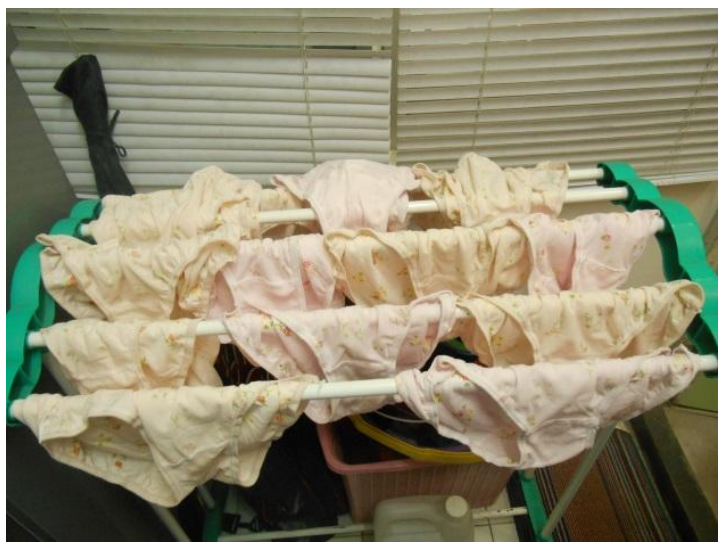

Gambar 3. Bercak dibiarkan dalam suhu kamar

\subsection{Hasil Pemeriksaan}


Hasil pemeriksaan PSA dengan menggunakan rapid tes SD Bioline Semen Inspection pada bercak celana dalam yang mengandung cairan mani masih memberikan hasil positif hingga hari ke 50. Dari hasil pemeriksaan tersebut memberikan petunjuk bahwa alat rapid tes ini mempunyai nilai sensitifitas yang cukup baik, karena hingga hari ke 50 masih dapat mendeteksi adanya PSA pada celana dalam yang mengandung cairan mani.

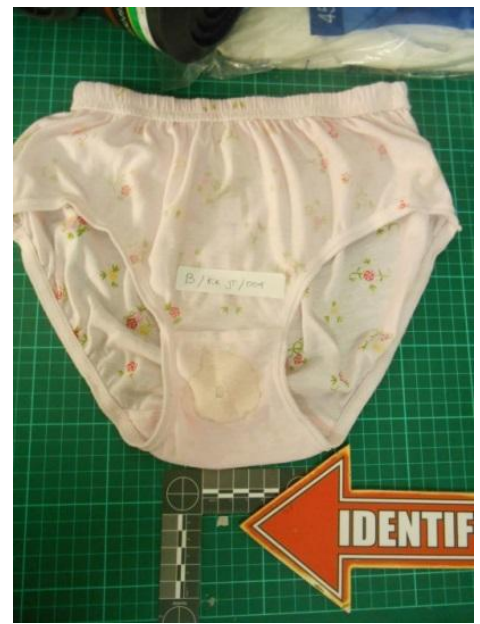

Gambar 4. Bercak digunting seluas $5 \mathrm{~mm}$ x $5 \mathrm{~mm}$

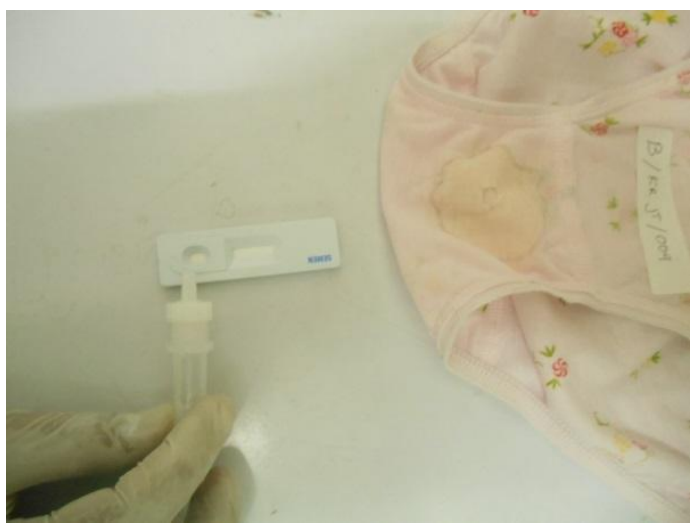

Gambar 5. Cairan ekstrak dimasukan ke alat rapid

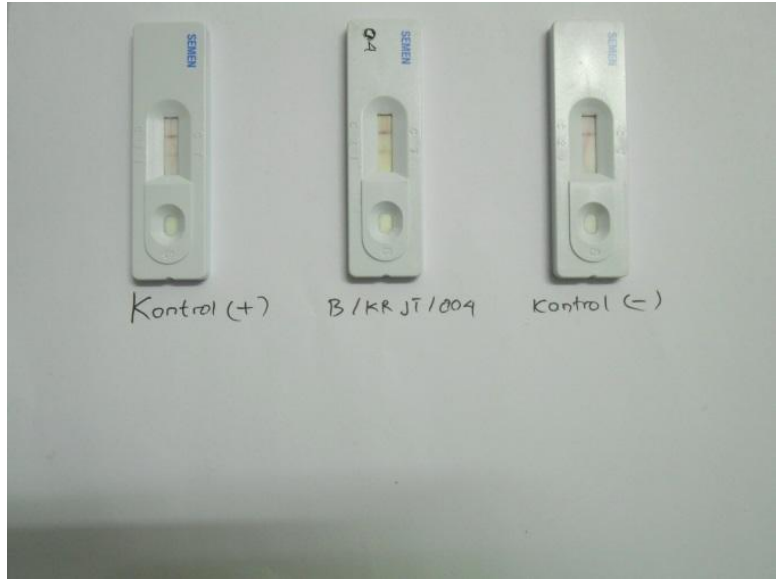

Gambar 6. Hasil positif pada hari ke 50

\subsection{Hasil Pembahasan}

SD Bioline Semen Inspection dapat digunakan untuk mendeteksi adanya kandungan PSA pada usapan vagina maupun bercak pada kain. Nilai diagnostik yang tertera pada petunjuk dalam alat ini sangat baik, yaitu $3 \mathrm{ng} / \mathrm{ml}$. Jika dibandingkan dengan persentase protein dalam cairan ejakulat yang $80 \%$ terdiri dari PSA, maka angka tersebut relatif baik dan dapat digunakan untuk kasus-kasus kejahatan seksual (Leonardo, 2015).

Pada awal tahun 2015, telah dilakukan penelitian oleh Leonardo. Pada penelitian tersebut dilakukan pengujian dengan menggunakan alat yang sama dengan penelitian ini, akan tetapi bahan pemeriksaan berasal dari usapan vagina. Dalam penelitian tersebut diperoleh jumlah bahan pemeriksaan yang berasal dari liang vagina sebanyak 40 sampel, dimana dari jumlah tersebut hanya diperoleh hasil yang positif sebanyak 4 sampel saja. Hal tersebut dapat terjadi oleh karena interval waktu persetubuhan dengan saat pengambilan sampel sudah mempunyai rentang waktu yang cukup lama, yaitu antara 1 sampai 7 hari (Leonardo, 2015)

Atas dasar itulah, peneliti ingin melakukan pengujian terhadap bercak celana dalam yang mengandung cairan mani. Peneliti menilai bahwa apabila pembuktian persetubuhan tidak dapat dibuktikan dari bahan pemeriksaan yang berasal dari usapan vagina, maka pemeriksaan dapat dilakukan dari celana dalam yang dipakai oleh korban kejahatan seksual. Bercak cairan mani yang 
terdapat pada kain mempunyai sifat yang lebih stabil oleh karena sudah dalam keadaan kering, sehingga tidak dapat diurai oleh adanya bakteri.

Dalam praktik penanganan kasus kejahatan seksual, sering korban melaporkan peristiwa yang dialaminya sudah cukup lama. Sehingga pembuktian menjadi sulit oleh karena tidak ditemukannya cairan mani pada liang vagina. Penelitian ini dilakukan sebagai solusi dari keadaan tersebut, yang mana pada keadaan di lapangan selain bercak pada celana dalam bahan pemeriksaanpun dapat dilakukan pada bercak yang ditemukan pada Tempat Kejadian Perkara (TKP), misalnya pada kain sprei, sarung bantal dan guling, selimut, dan sebagainya (Idries, 2011).

Pemeriksaan untuk membuktikan adanya kasus persetubuhan dalam pelayanan bidang Kedokteran Forensik cukup sulit. Hal tersebut disebabkan oleh karena bahan pemeriksaan yang didapat pada tubuh korban sangat sedikit. Selain permasalahan tersebut, kegiatan korban berupa mandi ataupun membersihkan alat kelamin juga menambah kesulitan tersendiri. Hal ini diperberat oleh keadaan dimana korban tidak langsung melaporkan dan dilakukan pemeriksaan paska terjadinya persetubuhan (Leonardo, 2015). Selama ini untuk pembuktian adanya cairan mani pada pelayanan forensik masih menggunakan metode Florence maupun berberio, tetapi kedua metode ini mempunyai nilai pembuktian yang rendah karena banyak faktor yang dapat membuat false positif diantaranya ektrak organ tubuh dan ekstrak putih telur (Budiyanto, et al., 1997). Pada beberapa penelitian menyebutkan bahwa bercak cairan mani dalam kain katun yang berumur 1 tahun masih memberikan hasil positif dengan menggunakan metode Florence, akan tetapi hasil positif yang diperoleh masih mempunyai nilai keragu-raguan yang cukup besar (Budiyanto, et al., 1997). Keterbatasan waktu menjadi kendala dalam penelitian ini, karena dalam interpretasi hasil setiap sampel membutuhkan waktu sekitar 10 menit untuk memperoleh hasil yang maksimal. Sementara untuk mempersiapkan sampel hingga ekstraksi membutuhkan waktu sekitar 2-5 menit, oleh karena itu tiap sampel membutuhkan waktu sekitar 12-15 menit. Dalam hal ini peneliti melakukan pemeriksaan tidak menggunakan sampel sekaligus 35, tetapi dipisah-pisah menjadi 5 sampel per satu kali pemeriksaan. Hal ini dilakukan karena peneliti khawatir apabila melebihi waktu 10 menit maka pembacaan hasil akan menjadi kurang maksimal.

Dari sampel yang diperoleh, seluruh volume dibercakkan pada celana dalam dan dibiarkan mengering pada suhu kamar dan selanjutnya dilakukan pengujian dengan alat rapid tes. Peneliti beranggapan bahwa jenis bahan kain, suhu disekitar dan lokasi bercak tersebut berada turut mempengaruhi hasil pemeriksaan. Selain itu, ukuran bercak yang diperiksa secara tersendiri juga dapat memberikan hasil yang berbeda mengingat alat ini mempunyai nilai sensitivitas tertentu.

Dari pemeriksaan hingga hari ke 50, seluruh subjek masih memberikan hasil yang positif sehingga pemeriksaan hari selanjutnya tidak dapat dilakukan oleh karena bercak cairan mani yang terdapat pada celana dalam sudah habis dipergunakan pada pemeriksaan hari sebelumnya. Dari pemeriksaan terhadap seluruh subjek hingga hari ke 50 masih memberikan hasil positif memberikan petunjuk bahwa alat ini mempunyai sensitifitas yang cukup baik sehingga dapat dipergunakan sebagai pemeriksaan penyaring untuk kasus kejahatan seksual. Pemeriksaan kasus-kasus kejahatan seksual untuk membuktikan adanya tanda-tanda persetubuhan adalah dengan menemukan adanya ejakulat dalam liang vagina, termasuk adanya kandungan PSA. Akan tetapi dalam keadaan tertentu dimana usapan vagina tidak dapat memberikan hasil yang maksimal, maka bahan pemeriksaan dapat diperoleh dari bercak yang terdapat pada celana dalam. Dengan demikian, hasil penelitian ini mendukung teori yang menyatakan bahwa; apabila tidak ditemukan adanya sel spermatozoa, tidak dapat disimpulkan bahwa bahan yang diperiksa tidak mengandung cairan mani, karena cairan mani terdiri dari dua komponen, yaitu komponen sel sperma dan komponen plasma (salah satunya PSA) (Hengky, 2011). Pada praktek pelayanan Forensik sering dijumpai keadaan dimana korban tidak langsung datang untuk dilakukan pemeriksaan sehingga menyebabkan pembuktian adanya kandungan ejakulat menjadi sulit ditemukan. Untuk mengatasi permasalahan tersebut, maka bercak pada celana dalam dapat dipergunakan sebagai pengganti usapan vagina dalam membuktikan adanya kandungan ejakulat. 


\section{KESIMPULAN DAN SARAN}

\subsection{Kesimpulan}

Hasil pemeriksaan terhadap seluruh subjek bercak cairan mani pada celana dalam menggunakan rapid tes SD Bioline Semen Inspection masih memberikan hasil positif sampai hari ke 50.

\subsection{Saran}

Penelitian sejenis dengan menggunakan rapid tes SD Bioline Semen Inspection pada bahan pemeriksaan berupa bercak cairan mani pada kain sangat disarankan dengan memulai pada hari ke 50, termasuk beberapa variabel yang dapat mempengaruhi stabilitas protein PSA, seperti PH, suhu, kelembaban, volume dan lain-lain. Data-data tersebut sangat diperlukan untuk membuat standar prosedur pemeriksaan PSA menggunakan rapid tes sehingga dapat dipergunakan pada penanganan kasus-kasus kejahatan seksual.

\section{DAFTAR PUSTAKA}

Astrup, BS TJ., Lauritsen, J., Ravn, P., 2012. "Detection of sprematozoa following consencual sexual intercourse." Forensic Scince International. 221:137-41.

Barret, K., Brooks, H., Boitano, S., Barman, S., 2010. The gonads: Development and function of reproductive system. In: Ganong's Review of medical phisiology. $23^{\text {th }}$ ed. New York: McGraw-Hill Companies, Inc.

Budijanto, A., Widiatmaka, W., Sudiono, S., Winardi, T., Mun'im, A., Sidhi., Hertian, S. et al, 1997. Pemeriksaan Laboratorium Sederhana. In: Ilmu Kedokteran Forensik. $1^{\text {st }}$ ed. Jakarta: Bagian Kedokteran Forensik dan Medikolegal, Fakultas Kedokteran Universitas Indonesia

Crawford, D., Waxman, S., 2001. The history of prostate specific antigen. In :
Prostate specific antigen. Brawer MK, editor. USA: Marcel Dekker, Inc.

Gefrieds, LA., Welch, KE., 2006. Serology and DNA. In: The forensic laboratory handbook procedures and practice. Mozayani A, Noziglia C, editors. New Jersey: Humana Press Inc.

Guyton, AC., Hall, JE., 2006. Reproductive and hormonal function of the male (and function of the pineal gland). In : Textbook of medical physiology. $11^{\text {th }}$ ed. Philadelphia: Elsevier Inc.

Haese, A., Becker, C., Diamandis, EP., Lilja, H., 2002. Adenocarsinoma of the prostate. In; Tumor Markers; Phisiology, Pathobiology, Technology and Clinical Application. Diamandis EP, Fritche HA, Lilja H, Chan DW, Schartz MK, editors. Washington DC: AACC Press.

Hardinge, PAJ., Wain, A., Watson, S., 2013. "Optimization of cholin testing using Florence Iodine Reagent, including comparative sensitivity and specificity with PSA and AP test." Science and Justice (53): 34-50.

Hengky., 2011. Perbedaan proporsi hasil pemeriksaan Prostate-Specific Antigen (PSA) yang positif dalam cairan mani dengan urine menggunakan Rapid Test Device (Tesis). Jakarta: Universitas Indonesia

Idries, AM., 2011. Sistematik Pemeriksaan Ilmu Kedokteran Forensik Khusus Pada Korban Kejahatan Seksual. Jakarta : Sagung Seto.

Jequier, AM., 2000. The anatomy and phisiology of the male genital tract. In: Male infertility : guide for the clinician. USA: Blackwell Science Ltd. 
Jurnal Biosains Pascasarjana Vol. 17 (2015) pp

(C) (2015) Program Pascasarjana Universitas Airlangga, Indonesia

Leonardo., 2015. Prostate-Specific Antigen dalam Pembuktian Persetubuhan (Tesis). Jakarta : Universitas Indonesia.

Lunetta, P., Phill, SL., 2009. "Positive prostatespecific antigen (PSA) reaction in post-mortem rectal swabs : A cautionary note." Journal of Forensic and Legal Medicine; $16(7): 99$

Manfred, NH PhD., Oscar, Rudin., Urs, Borer., Christian, Gehrig., Michail, Thali MD., 1999. "Evaluation of Prostate-Specific Antigen (PSA) Membrane test Assay for the Forensic Identification of Seminal Fluid." Journal of Forensic science. 57-60

Meilia, PDI., 2012. "Prinsip pemeriksaan dan penatalaksanaan Korban (P3K) Kekerasan Seksual." Cermin Dunia Kedokteran. 39(8) : 83.

Owen, DH., Katz, DF., 2005. "A review of the physical and chemical properties of human semen and the formulation of a simulant." Journal of andrology; 459.

Sampurna, B., Samsu, Z., 2003. "Kekerasan terhadap perempuan." In: Peranan Ilmu Forensik Dalam Penegakan Hukum.

Saferstein, R., 2004. Criminalistic An Introduction

To Forensic Science. Rosenberg $B$, editor. New Jersey: Pearson Education; 62-74.

Semen Inspection. Available from : http://macmedeastafrica/product detail,asp?a=353

Susanti, R., Sampurna, B., Winardi, T., Prayanti, M., 2007. Pemeriksaan kadar seng secara kuantitatif pada cairan vagina untuk pembuktian persetubuhan (tesis). Jakarta: Fakultas Kedokteran Universitas Indonesia.
Stenman, UH., 2001. Biochemistry and basic science, in : prostate specific antigen. Brawer MK, editor, USA: Marcel Dekker, Inc.

Steven, P. Balk Y-JK and J. Bubley., 2003. "Biology of Prostate-Specific Antigen." Journal of Clinical Oncology, 21(2):91-383. 